\title{
The effect of public investor activism on trust: A case study in the asset management sector
}

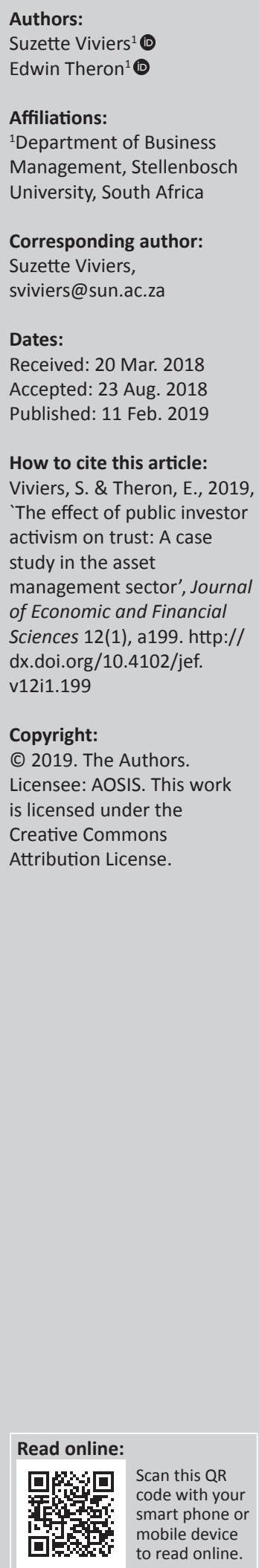

Orientation: Compromised global trust levels appears to be one of the lasting legacies of the 2007 financial crisis, also in the financial services industry. In order to rebuilt trust, it is not only important to identify the drivers of trust, but also to assess the contexts within which trust is cultivated.

Research purpose: The researchers investigated the impact that this announcement and a subsequent apology by Futuregrowth's chief investment officer (CIO) had on trust in the asset management sector.

Motivation for the study: Trust could be compromised when investors publicly engage with investee companies on contentious issues. As most investor activism in South Africa takes place in private, a unique research opportunity presented itself when Futuregrowth Asset Management publicly announced that they would suspend their funding to six state-owned enterprises (SOEs). Futuregrowth is the biggest private fixed-income asset manager in Africa and is renowned as a responsible investor.

Research approach/design and method: Content analysis was performed on 31 articles published in financial newspapers and magazines. In addition, semi-structured personal interviews were conducted with the $\mathrm{CIO}$ of Futuregrowth, another member of his team and six prominent local asset managers.

Main findings: The findings suggest that asset managers who wish to engage with investee companies in South Africa, especially SOEs, should preferably do so in private as a first recourse. When they do decide to speak out in public, they should focus on maintaining both calculative and affective trust. Failure to recognise the importance of affective trust, especially during periods of socio-political and economic uncertainty, could jeopardise trust in the asset management sector.

Practical/managerial implications: The evidence suggests that affective trust is increasingly important in the chosen sector. Asset managers should no longer only focus exclusively on credibility, reliability and competence but should also give due consideration to the affective trust elements of integrity and fairness.

Contribution/value-add: The findings are particularly pertinent in countries with small stock exchanges and high degrees of director interlocking. The research methodology adopted in this study represents a novel contribution to research in the asset management field.

\section{Introduction}

'It is in your hands to create a better world for all who live in it'. This quote by the late Nelson Mandela seems at odds with the current reality in South Africa where politicians and business leaders are increasingly acting in their own best interests. According to the 2017 Edelman Trust Barometer, only $15 \%$ of South Africans trust the government and only slightly more than half $(56 \%)$ of the surveyed individuals trust private businesses (Edelman Trust Barometer 2017a). Trust in both spheres was no doubt further eroded when RSA bonds and bonds issued by the four largest banks were downgraded to junk status in April 2017.

A review of the literature shows that trust is particularly important in the financial services industry, given the high levels of risk and a sense of vulnerability (Alalwan et al. 2015; Bachmann, Gillespie \& Priem 2015). Unfortunately, rising incidences of insider trading, fraud and pyramid schemes are eroding trust and relationship management efforts in this industry (Hurley, Gong \& Waqar 2014).

It has been argued that trust is best developed and nurtured when investors and their appointed asset managers engage with investee companies in private (McNulty \& Nordberg 2016). This is particularly true in countries with small stock exchanges and a high level of director interlocking. 
The number of companies listed on the Johannesburg Stock Exchange is not only small but has also decreased in recent years (Boshoff \& Schulshenk 2014; Market Profile June 2018). To compound matters, the percentage of directors serving on three or more boards simultaneously has risen (Williams, Deodutt \& Stainbank 2016). In such an environment, characterised by a high level of interconnectivity, trust can easily be jeopardised should asset owners or asset managers publicly 'name and shame' directors. As most investor activism in South Africa takes place behind closed doors, a unique research opportunity presented itself when Futuregrowth Asset Management publicly announced in 2016 that they would suspend funding to six state-owned enterprises (SOEs).

Futuregrowth is the biggest private fixed-income asset manager in Africa, managing approximately \$2.4 billion worth of assets (About us 2017). Driven by their desire to make a positive contribution to society, they have pioneered several development funds focusing on low-income housing, urban regeneration, shopping centres in rural areas and townships, sustainable agriculture and renewable energy.

On 31 August 2016, Futuregrowth's chief investment officer (CIO), Andrew Canter, publicly announced that they would not roll over existing debt or extend new debt to the South African power utility Eskom, rail and ports operator Transnet, the South African National Roads Agency (SANRAL), the Land and Agricultural Development Bank of South Africa (Land Bank), the Industrial Development Corporation (IDC) and the Development Bank of Southern Africa (DBSA). Canter justified the funding freeze citing serious governance concerns within these entities (Cohen 2016a).

Journalists called the announcement an unprecedented, courageous move - one that 'might even spark a financial revolution' (Hogg 2016a). As Treasury bond yields rose and the South African rand weakened to its lowest level in more than 7 weeks (Potelwa 2016), Canter had to contend with harsh criticism from the investment public via social media. Futuregrowth's parent company, Old Mutual plc, also condemned the asset manager's public approach, as did executives of the targeted SOEs, government ministers and some clients (Anon 2016b; Smith 2016). Research shows that hostilities often occur when investors publicly engage with investee companies (Brav et al. 2008).

As far as could be ascertained, no previous studies have investigated the effect of public investor activism on trust in the asset management sector. Most researchers have concentrated on the impact of such activism on the market values of investee companies and changes to corporate policies and practices post-engagement (Kolstad 2016; Wen 2009). It can be argued that both calculative and affective trusts are essential in building and maintaining high levels of trust in the asset management sector. Failure to do so could jeopardise the survival and prosperity of entities in this sector.

Various aspects relating to trust will be discussed in the following sections. Next, the methods used to collect and analyse the data will be presented along with the main findings of the study. Finally, pertinent recommendations for asset managers will be offered.

\section{Exploring trust Defining trust}

One of the key building blocks of a sound relationship is trust (Morgan \& Hunt 1994). Despite a plethora of academic studies on the importance of trust, the exact meaning of the construct remains elusive. The lack of conceptual clarity is apparent in the variety of definitions proposed in the literature. One of the earliest definitions of trust was provided by Moorman, Deshpandé and Zaltman (1993) who define the construct as 'a willingness to rely in an exchange partner in whom one has confidence'. This definition emphasises the exchange partner's trustworthiness, which, in turn, is based on expertise, reliability and intentionality. Morgan and Hunt (1994) concur and claim that trust exists when one party has confidence in an exchange partner's reliability and integrity.

Despite the different definitions of trust (Ennew \& Sekhon 2007), a number of key themes are embedded in the construct, namely that exchange partners are often interdependent on each other and that trust is critically important when risk is prevalent and parties are vulnerable. From an academic perspective, trust is a complex phenomenon, resulting in a situation where scholars of different disciplines have defined trust through alternative lenses, resulting in divergent rather than convergent theories (Moin, Devlin \& McKechnie 2015). Despite this divergence in definitions, researchers appear to agree that trust essentially consists of two distinct dimensions, namely a calculative (or cognitive) dimension and an affective (or emotional) dimension (Wilson, Straus \& McEvily 2006).

The calculative dimension of trust is based on an evaluation of the partner's predictability, dependability, credibility, reliability and competence (Aulakh, Kotabe \& Sahay 1996; Wu, Wu \& Wang 2016; Young-Ybarra \& Wiersema 1999). According to Chua, Ingram and Morris (2008), calculative or cognition-based trust refers to trust 'from the head', a judgement based on evidence of another's competence and reliability. Calculative trust was found to be performance-based in nature with rationality that is used as the basis for trusting the other party (Zur, Leckie \& Webster 2012). This dimension of trust could therefore be equated to a calculative decision that needs to be taken on the continuance of a relationship. The calculative dimension is based on the rational evaluation of risks, rewards, controls and information derived from beyond the exchange interface. Acting with cognitive trust could prevent role players from behaving opportunistically (Tyler \& Stanley 2007).

Not all exchanges can be accounted for by rational choices, resulting in an emphasis on the more emotional or affective dimension of trust (Dowell, Morrison \& Heffernan 2015). This affective dimension of trust focuses on the confidence that partners have on the basis of feelings or emotions. According to Rempel, Holmes and Zanna (1985), these feelings tend to be generated by the level of care and concern 
the partner demonstrates; also, this component of trust is characterised by feelings of security (Johnson \& Grayson 2005). Zur et al. (2012) furthermore found that this type of trust is emotionally based and is characterised by the perceived strength of the relationship and the sense of security felt in the relationship.

Affective trust is further characterised by integrity, benevolence, likeability, honesty, judgement, fairness and faith (Smith \& Barclay 1997; Young-Ybarra \& Wiersema 1999; Zaheer, McEvily \& Perrone 1998). In contrast to calculative trust, affective-based trust refers to 'trust from the heart' based on one's own emotions and senses of the other's feelings and motives (Chua et al. 2008). In summary, it can be argued that calculative trust is objective, whereas affective trust is more subjective in nature (Pi, Liao \& Chen 2012).

Warrington, Abgrab and Cladwell (2000) established that trust in business relationships is typically built on calculative grounds. Nowhere is this more applicable than in the financial services industry (Wang, Ngamsiriudom \& Hsieh 2015). Tyler and Stanley (2007), however, assert that the financial services industry is characterised by high levels of both calculative and affective trust, not only on an interpersonal level, but also on an organisational and interorganisational level.

\section{Importance of trust}

The dawn of the new millennium saw a renewed interest in the topic of trust albeit from a multidisciplinary perspective (Tyler \& Stanley 2007). The importance of trust is so welldocumented that it can be viewed as the universally accepted basis for all human interaction (Leisen \& Hyman 2004). Berry (1995) refers to trust as the glue that ties consumers to the products and services that they acquire.

As indicated earlier, trust is pivotal in the financial services industry. Devlin et al. (2015) even claim that trust is to be expected as:

... anybody who gives over significant amounts of money to another party must have a basic level of trust that resultant fiduciary responsibilities will be met and that their money will not disappear overnight. (p. 235)

The 2007-2009 global financial crisis, however, eroded trust on a global scale; to such an extent, that rebuilding trust appears to be the new 'normal' in business (Hansen 2014). Scandals have further diminished trust in the financial services industry (Moin et al. 2015). Not only has the 20072009 global financial crisis negatively affected trust in general, but it has also resulted in a loss of confidence in financial institutions in general (Uslaner 2010). Vašková and Vašková (2010) observe that the crisis took the world by surprise, and resulted in a complete breakdown of trust. It was therefore not surprising to learn that the crisis was widely referred to as a 'crisis of trust' among an outraged public (Barry 2009).

\section{Current state of trust}

Although trust can be defined and measured differently, the Edelman Trust Barometer is recognised as one of the most reputable measures. The Barometer, which originated in 2001 and which measures the perceptions of more than 33000 individuals, annually measures trust levels in governments, private businesses, non-governmental organisations and the media the world over. Inferences on the general levels of trust are made at a country and industry level. As indicated in Figure 1, trust in private businesses decreased from 2016 to 2017 in 18 of the 28 surveyed countries.

The average level of trust for all the surveyed countries was $52 \%$. Approximately $56 \%$ of the surveyed individuals trusted private businesses in South Africa. Although the level of trust in South Africa is seemingly higher than that in other emerging economies, it has decreased by 4\% from 2016 to 2017.

South Africa was one of only five countries where Chief Executive Officer (CEO) credibility was above 50\% (52\%). Although this statistic appears to be positive, it should be noted that it deteriorated by $16 \%$ on a year-to-year basis. In an industry-specific report, Edelman found that, at 54\%, the financial services industry had the lowest level of trust of all the reported industries in 2017 (Edelman Trust Barometer 2017b). Within this industry, the asset management sector had the lowest overall trust percentage, namely 50\%. This finding is particularly disconcerting given the importance of trust in this sector (Bachmann et al. 2015).

An alarming finding of Edelman's financial services industry report (Edelman Trust Barometer 2017b) is that trust in this industry is increasingly built on the perceptions of peers, as opposed to relying on experienced role players in the industry. For example, trust in 'a person like yourself' and in 'technical experts' were both reported to be $60 \%$, whereas trust in CEOs was measured at a mere $37 \%$ and in boards only 35\%. Peers are therefore regarded as credible experts (Edelman Trust Barometer 2017b). The preceding discussion necessitates an investigation into the importance of the rebuilding of trust in private businesses in general and in financial services providers in particular.

\section{Restoring trust}

The well-known saying that 'trust takes a long time to build and a moment to be destroyed' is particularly relevant in the financial services industry. It is generally assumed that the emotional dimension of trust is often neglected by practitioners in this industry (Chong \& Tuckett 2014). It is important to note that trust is a personal and reciprocal process that is shaped by soft skills. As Green (2014) puts it:

Trust is not gained by preaching it, mandating it, incentivising it or demanding it. We trust people, not policies. We trust those people who behave in trustworthy ways toward us, and equally important - we trust those people who trust us. (p. 20) 


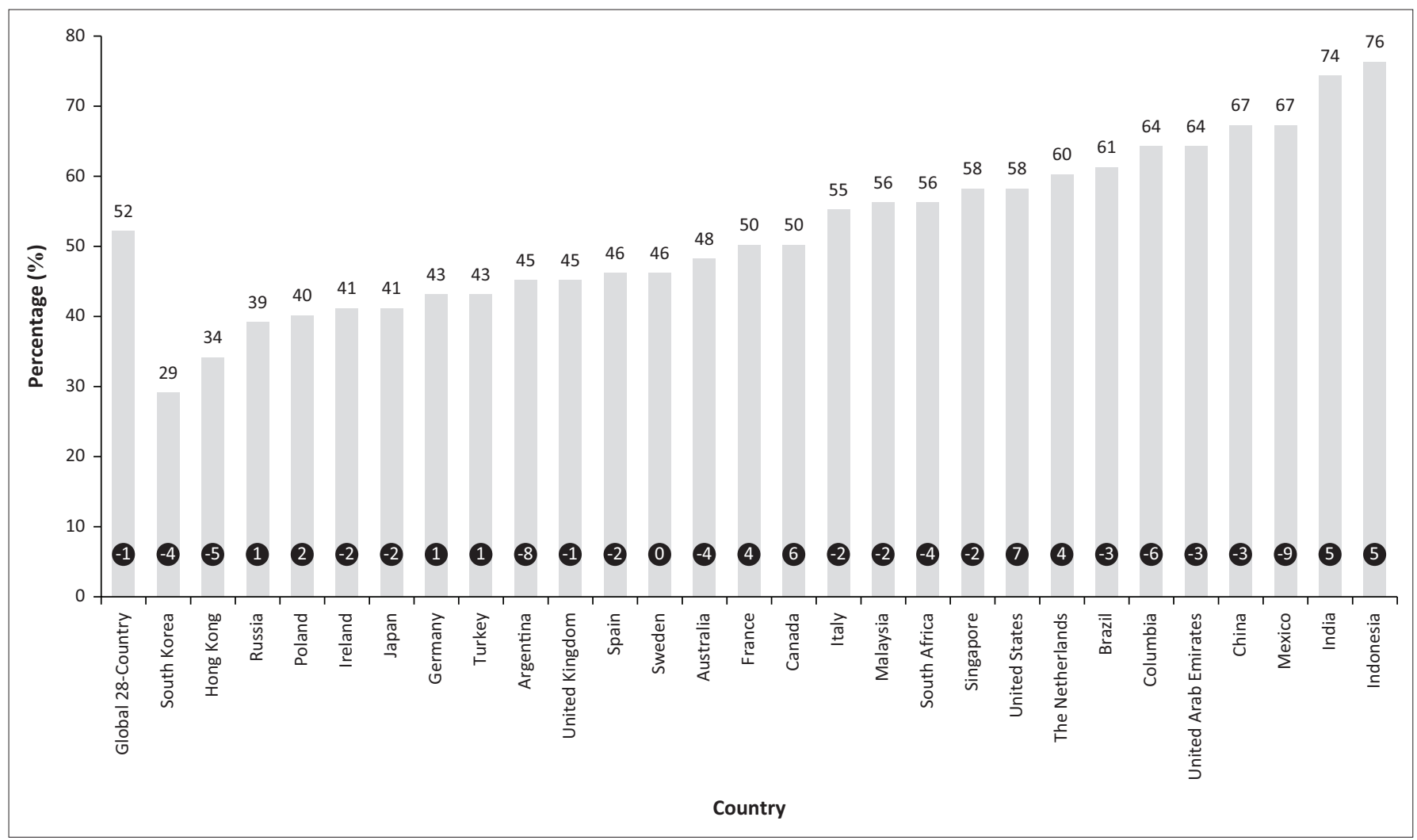

Source: Edelman Trust Barometer, 2017a, Global annual study, 2017, Global results, viewed 09 January 2018, from http://www.edelman.com/trust2017/ Note: The numbers in black circles refer to the percentage increase or decrease over the period 2016-2017.

FIGURE 1: Trust in private businesses: A global perspective.

A changing financial services landscape requires policymakers to rethink their current approaches to decisionmaking. From the onset, they need to be aware of the different ways in which trust can be built, broken and restored in this industry. More emphasis should be placed on the impact of behavioural biases on financial decision-making. The literature suggests that rebuilding trust in the financial services industry could be attained by focusing on the key building blocks (or antecedents) of trust. Prior studies provide significant evidence confirming the relationship between satisfaction and trust (Garbarino \& Johnson 1999; Leisen \& Hyman 2004), particularly in the financial services industry (Román 2003). Abdul-Muhmin (2005) confirms that satisfaction is positively associated with the perceptions of service providers' benevolence and credibility. The positive impact of effective corporate communication on the formation of trust is equally well reported (Kang et al. 2005; MacMillan et al. 2005). Canary and Cupach (1988) found a positive relationship between satisfaction with the level of communication and trust where trust needs to be restored. Gounaris and Prout (2009) argue that it is imperative to use appropriate communication skills to restore trust.

The literature further confirms the positive effect that competence has on the management of trust (Coulter \& Coulter 2003). Perry, Cavaye and Coote (2002:79) define competence as 'the degree to which business transactions meet performance expectations'. Furthermore, Selnes (1998) contend that competence constitutes both technical expertise regarding products and services, and knowledge of customers, organisations, markets, competitors and the industry.

Customisation was found to be a further building block of trust (Gill, Flaschner \& Shachar 2006). The key premise behind customisation refers to the extent to which a service provider is willing to accommodate their customers' changing needs (Homburg, Giering \& Menon 2003). Yilmaz, Sezen and Ozdemir (2005) likewise ascertain that exchange partners should be willing to act responsively and to adapt their service offerings whenever specific requests are made. Homburg et al. (2003), furthermore, argue that an exchange partner's flexibility can contribute to expanding and solidifying their relationship. In the financial services industry, Gill et al. (2006) contend that customisation is dependent on the competence of staff, as individual clients' needs can only be identified by people who are competent to do so. The study also contends that customisation is often linked to empathy, which is an affective element of trust.

Another building block that is often used to manage or restore trust is shared values. Studies by Kang et al. (2005), MacMillan et al. (2005) and Morgan and Hunt (1994) confirm that if the relevant parties' goals are congruent, it will result in increased levels of trust. Similarly, Anderson and Weitz (1989) emphasise the positive effect of goal congruence on trust, pointing out that goal congruence is a more confined concept than shared values. Johnson and Grayson (2005) report a significant positive relationship between similarity 
and affective trust. This relationship occurs because the detection of similarity in others confirms an individual's interpretation of the environment, which, in turn, provides an environment conducive for the development of trust (Johnson \& Grayson 2005).

\section{Method}

Given the exploratory nature of this study, a phenomenological research paradigm was deemed appropriate. Futuregrowth's public announcement on 31 August 2016 served as a valuable case study to investigate the dynamics of trust in the asset management sector. Qualitative secondary data were therefore collected. Articles in financial newspapers and magazines such as Bloomberg, Business Day, Moneyweb, Fin24 and Financial Mail, both in hard copy and electronic format, were collected over a 3-month period commencing on 31 August 2016. The following keywords were used to identify relevant articles: Futuregrowth Asset Management, Andrew Canter, SOEs, Eskom, Transnet, SANRAL, Land and Agricultural Development Bank of South Africa, Land Bank, IDC and DBSA. This data collecting process yielded 31 usable articles.

Content analysis was used to analyse the textual data (Finfgeld-Connett 2014). This approach was chosen as the authors had clearly defined elements of calculative and affective trust. The analysis started with reading the articles repeatedly to achieve immersion and a sense of the complete case study. The articles were then analysed in relation to a structured matrix. As indicated in Table 1, the main categories in the categorisation matrix were calculative and affective trust. Four sub-categories were used to identify keywords relating to calculative trust, whereas five sub-categories were used for affective trust (integrity, honesty, fairness, positive feelings and negative feelings). As some of trust elements are interrelated, they are often used interchangeably in the literature. During the coding process, a deliberate attempt was, however, made to keep the elements separate. To enhance the study's trustworthiness, the authors coded the articles independently and then compared results. As suggested by Elo and Kyngäs (2007), authentic citations were also included in the findings section of the article to increase trustworthiness.

Hsieh and Shannon (2005) rightfully argue that a challenge associated with content analysis is the failure to develop a complete understanding of the context of the study. To address Hsieh and Shannon's (2005) concern, the authors described the case in detail and conducted a semi-structured personal interview with Canter and one of his colleagues. The aim of the interview was to verify the facts and to gain more insight into the motives and consequences of the 31 August 2016 announcement. Canter provided explicit permission that his name and that of Futuregrowth may be published.

Semi-structured personal interviews were also conducted with six prominent local asset managers to establish why

TABLE 1: Deduction of the words and phrases used in the content analysis. $\dagger$

\begin{tabular}{|c|c|c|c|c|}
\hline Dimension & Element & Definition & Source & Words and phrases sought during the content analysis \\
\hline \multirow[t]{4}{*}{ Calculative } & Credibility & $\begin{array}{l}\text { The believability of a source. Credibility } \\
\text { largely rests on the perception of } \\
\text { trustworthiness and expertise. It also } \\
\text { relies on the perceived veracity } \\
\text { (accuracy) of information provided by a } \\
\text { source. }\end{array}$ & Metzger and Flanagin (2013) & $\begin{array}{l}\text { Those showing that Futuregrowth and Canter could be } \\
\text { relied upon (such as believability, trustworthiness and } \\
\text { accuracy). }\end{array}$ \\
\hline & Reliability & $\begin{array}{l}\text { The ability to perform a promised } \\
\text { service accurately and dependably. }\end{array}$ & Xifei and Jin (2015) & $\begin{array}{l}\text { Those illustrating that Futuregrowth could perform a } \\
\text { promised service (such as dependability, responsibility, } \\
\text { accountability and acknowledgement of duties towards } \\
\text { clients). }\end{array}$ \\
\hline & Competence & $\begin{array}{l}\text { The degree to which a business } \\
\text { transaction meets performance } \\
\text { expectations. }\end{array}$ & Perry et al. (2002) & $\begin{array}{l}\text { Those indicating that Futuregrowth is capable of meeting } \\
\text { clients' expectations (such as skills, knowledge and } \\
\text { abilities). }\end{array}$ \\
\hline & Uncertainty avoidance & $\begin{array}{l}\text { The manner in which a nation or society } \\
\text { deals with uncertainties or an unknown } \\
\text { future. }\end{array}$ & $\begin{array}{l}\text { Tran, Nguyen and Nguyen } \\
\text { (2016) }\end{array}$ & $\begin{array}{l}\text { Those referring to the uncertainty and risks introduced by } \\
\text { unanticipated changes in the political environment in } \\
\text { South Africa and changes in SOE governance (such as } \\
\text { unexpected changes to markets, inputs, transactions, } \\
\text { outputs and the environment). }\end{array}$ \\
\hline \multirow[t]{4}{*}{ Affective } & Integrity & $\begin{array}{l}\text { The degree to which a partner adheres } \\
\text { to a set of acceptable principles. } \\
\text { Integrity is defined as steadfast } \\
\text { adherence to an ethical code. }\end{array}$ & $\begin{array}{l}\text { Pinto, Slevin and English } \\
\text { (2009) }\end{array}$ & $\begin{array}{l}\text { Those showing that Futuregrowth and Canter have strong } \\
\text { moral principles (such as adherence to written and moral } \\
\text { agreements, being morally upright, standing up for what is } \\
\text { right and abiding to moral principles). }\end{array}$ \\
\hline & Honesty & $\begin{array}{l}\text { The complete disclosure of information } \\
\text { regarding relevant knowledge, facts } \\
\text { or findings that are pertinent to a } \\
\text { specific situation (and which a person } \\
\text { is aware of). }\end{array}$ & $\begin{array}{l}\text { Turner, Edgley and Olmstead } \\
\text { (1975) }\end{array}$ & $\begin{array}{l}\text { Those indicating that Futuregrowth and Canter are truthful } \\
\text { and sincere in conveying information (such as openness, } \\
\text { frankness and sincerity). }\end{array}$ \\
\hline & Fairness & $\begin{array}{l}\text { The equal treatment and justification of } \\
\text { departures from equality. }\end{array}$ & Muylle and Standaert (2016) & $\begin{array}{l}\text { Those showing Futuregrowth and Canter's commitment to } \\
\text { be impartial, to avoid favouritism and discrimination (such } \\
\text { as equality, fairness and impartiality). }\end{array}$ \\
\hline & Feelings & $\begin{array}{l}\text { The perception of an emotion which } \\
\text { ranges between a sense of pleasure or } \\
\text { pain (therefore establishing a } \\
\text { connection to the subset of reward and } \\
\text { aversion mechanisms that are an } \\
\text { integral part of emotional behaviour). }\end{array}$ & Damasio (2004) & $\begin{array}{l}\text { Those indicating that a decision was made on emotional } \\
\text { grounds (which include both positive and negative } \\
\text { feelings). Examples of positive feelings included care, } \\
\text { excitement, sociability and self-confidence, whereas } \\
\text { negative feelings comprised anger, judgement, concern, } \\
\text { detachment, fear and fatigue. }\end{array}$ \\
\hline
\end{tabular}

Note: Please see the full reference list of the article, Viviers, S. \& Theron, E., 2018, 'The effect of public investor activism on trust: A case study in the asset management sector', Journal of Economic and Financial Sciences 11(1), a199. http://dx.doi.org/10.4102/jef.v11i1.199, for more information.

SOE, state-owned enterprise.

$\dagger$, It is important to note that the elements identified in this table are not mutually exclusive. 
they did not follow Futuregrowth's public activism approach. Judgemental sampling was used to identify experienced asset managers employed at large local asset management companies. Their job titles included Director and CIO, Joint CIO, Lead Fund Manager, Head: Fixed Income Portfolio Management, Head: Environment, Social and Governance Engagement and Manager: Sustainable Investment Practices. All of the interviewees had been asset managers for more than 10 years and all but one had postgraduate qualifications. A thematic analysis was used to analyse the data collected from these interviews.

Rigour was ensured by using an appropriate analytical procedure to analyse the textual data. Care was also taken to confirm that the interviewees were knowledgeable individuals. Validity and reliability were furthermore ensured by collecting and analysing the data concurrently. A possible limitation of the study is that only six interviews were conducted with local asset managers. It might thus be possible that other asset managers had different views on the matter. The selected interviewees, however, represented some of the largest financial institutions in the country. Before presenting the findings, more details are provided on Futuregrowth's motives for the lending ban and selected reactions to the announcement. These themes will be discussed next.

\section{The Futuregrowth case study Futuregrowth's motives for the state-owned enterprise lending ban}

Canter justified the funding freeze by referring to the risks emanating from opaque governance, budgeting and approval processes at the targeted SOEs. The lender's main concerns centred on the lack of independence of the SOEs' boards politically exposed persons, directors serving on the credit committees, the mandates of these committees, the limited number of independent non-executive directors and opaque processes that deal with large and connected loans (in the case of lending SOEs) and procurement (in the case of infrastructure SOEs). The decision by Canter to freeze the funding was made in the light of the asset manager's commitment to sound corporate governance (Anon 2016c).

Canter pointed out that South African President Jacob Zuma's decision to introduce a new panel to oversee SOEs (23 August 2016) lacked clarity and context. As Pravin Gordhan, the finance minister at the time, and other ministers already performed this overseeing role, the question arose as to whom the SOEs would have to answer to in the future. Canter argued that this uncertainty affected forward-looking credit assessments unfavourably (Cohen 2016a).

He contended that asset managers are 'caretakers of peoples' savings'. As such, he argued that it was entirely appropriate for Futuregrowth to deny capital to the targeted SOEs (Anon 2016a). Canter emphasised Futuregrowth's fiduciary duty to make reasoned and defensible decisions. He reiterated that asset managers have to answer to their clients for decisions made on their behalf. He furthermore stated that it was never his goal to punish South Africa, and that the announcement was merely taken against the background of Futuregrowth's fiduciary responsibility. This responsibility is particularly important for asset managers who are signatories of the Principles for Responsible Investment and the Code for Responsible Investing in South Africa. Futuregrowth has long been signatories of both of these initiatives

\section{Canter (2016) noted that intermediaries should keep:}

... business managers from going wild. If we do that for SOEs and [consequently] improve governance reporting, we would have done a service both for them and for the country.

He repeatedly said that he is a 'credit guy' and added: 'I want to be proud of what we do and [want to] be accountable for what we do' (Canter 2016). He stressed that Futuregrowth's decision was not taken lightly. Although the lender had longstanding relationships with all the targeted SOEs, the lender needed more information to assess the long-term creditworthiness of these entities (Cohen 2016a): 'We cannot provide funding without having clearer sight of, and comfort around, the governance and decision-making of the[se] entities' (Anon 2016a).

The Futuregrowth team was under the impression that other asset managers would share their concerns about the targeted SOEs, seek to improve governance and reporting of the SOEs and would follow their example. In Canter's words: 'We expect there to be similar announcements confirming an investment strike in the wake of President Zuma's attacks on the finance minister' (Canter 2016). This expectation was based on the notion that all asset managers need the same information to make justifiable investment decisions (Canter 2016). Yet, nothing came from this presumption of a collective, public effort (Potelwa \& Cohen 2016).

\section{Reactions from selected stakeholders}

Two days after Futuregrowth's announcement, Eskom declared that they would not invest a further R100 million of its Pension and Provident Fund in Futuregrowth's Development Equity Fund III (Anon 2016c). Eskom's chief financial officer also remarked that Futuregrowth's decision did not affect them. He claimed that Eskom's funding plan for the year would be realised without Futuregrowth's contribution (Slabbert 2016). Another Eskom executive claimed that 'if they are not going to lend us money, then I suppose it is fine, we will go elsewhere' (Cohen 2016b). These executives failed to realise that the electricity provider might experience serious challenges if they could not roll over existing debt (Slabbert 2016). Despite Eskom's reaction, they agreed to meet with Canter to discuss the lender's concerns in private.

Transnet also claimed that they already met their full borrowing requirement for the 2016/17 financial year (of which $1.25 \%$ was provided by Futuregrowth). Transnet's 
CEO dismissed Futuregrowth's decision by saying that he did not lose any sleep over it. He regarded the SOE as a credible and reliable borrower based on its stand-alone credit profile and investment grade credit rating (Peyper 2016b): 'If they decide not to buy Transnet bonds, it is their problem.' He added that Transnet would continue to raise funds through domestic and international debt markets and asserted that the lender's decision was 'unfair and unfortunate'. He also found it regrettable that Futuregrowth 'overlooked' the channels of communication available to them. The CEO referred to the fact that large investors, such as Futuregrowth, are in a better position than smaller ones to engage with executives directly (Ryan \& Schneider 2002).

In briefing the Parliamentary Portfolio Committee on Public Enterprises, Transnet's CEO posited that Futuregrowth was 'playing to the public gallery'. As the CEO regarded this SOE to be a credible and reliable borrower (Peyper 2016a), he considered suing Futuregrowth for damages.

The resistance by Eskom and Transnet was not entirely unexpected, especially as South African investors enjoy high levels of legal protection and do not have to revert to public forms of activism (Viviers \& Smit 2015). Investee companies and SOEs are therefore not accustomed to being openly criticised. In the months following Futuregrowth's public announcement, the credit ratings of both Eskom and Transnet have been downgraded and both have struggled to raise new debt (Moola 2017; Thompson 2017).

Public Enterprises Minister, Lynne Brown, expressed her surprise at Futuregrowth's decision given the 'positive financial performance of some SOEs'. She also voiced her concerns about the negative perceptions that the public announcement created about the SOEs in question (Anon 2016d). The minister believed that these perceptions were unwelcome at a time when several of the targeted SOEs were facing credit-rating downgrades. She subsequently invited all current and potential investors to engage directly with her and the targeted SOEs about any concerns they might have (Potelwa \& Cohen 2016). Brown also requested an urgent meeting with Canter and the CEO of Old Mutual, Futuregrowth's parent company. National Treasury welcomed calls by the minister to resolve matters quickly (Omarjee 2016).

Canter confirmed that both the Land Bank and the IDC immediately contacted him after the public announcement and agreed to due diligence investigations. After conducting a comprehensive review of Land Bank's governance and investor protection mechanisms, Futuregrowth announced that they would resume lending to this SOE (Mokhema \& Gumede 2016). A few days later, the lender also lifted their funding ban on the IDC (Le Cordeur 2016). As in the case with Land Bank, Futuregrowth's review was conducted to obtain a deeper understanding of the board's independence, autonomy, decision-making rights, commitment to fiduciary responsibility and the SOE's relationship with government.
According to the IDC's Chief Financial Officer, engagements during the due diligence investigation were constructive and robust. Both SOEs acknowledged Futuregrowth as a key funder and one whose support was vital to achieve their mandates. They undertook to maintain the highest levels of corporate governance to protect the interests of funders and to report regularly and publicly on matters of interest (Le Cordeur 2016).

Ongoing engagements between the DBSA and Futuregrowth not only resulted in a 'restored and strengthened' relationship between them, but it also resulted in the lender resuming funding to the DBSA on 21 November 2016 (Maake 2016). This SOE committed itself to implement Futuregrowth's recommendations such as increasing their reporting on board and investment activities and implementing additional governance structures.

The day after Futuregrowth's public announcement, Old Mutual distanced itself from the decision. A company spokesperson said that although Futuregrowth had a mandate to make independent decisions on behalf of their clients, their comments did not reflect the broader views of Old Mutual (Potelwa \& Cohen 2016). The spokesperson made it clear that Old Mutual:

... values the broad and deep relationships that it has developed with SOEs over many years and believe that these commercial partnerships are critical in driving economic growth and financial inclusion in the country. (Rose, Hasenfuss \& Bisseker 2016; Smith 2016)

Another Old Mutual representative stressed that a public statement was not an appropriate forum for engaging with the targeted SOEs: 'We believe SOEs, particularly the ones mentioned in the statement, need to be engaged first-hand. [As such] we regard their [Futuregrowth's] statement as unfortunate and regrettable' (Rose et al. 2016). Old Mutual stressed that a more constructive model of engagement was necessary when interacting with SOE partners (Anon 2016b). A senior manager at Old Mutual acknowledged that it was arguably not appropriate for Futuregrowth to communicate their decision in advance, pointing out that they should at least have been informed because of the highly sensitive nature of the topic (Bendile 2016). Old Mutual committed themselves to ongoing constructive dialogue with the targeted SOEs (Potelwa \& Cohen 2016).

Canter justified Futuregrowth's stance by stating that they considered the news to be material non-public information. The sharing of this kind of information is highly regulated in the South African context. The investment team knew that it could affect the prices of the targeted entities' bonds. Bond yields did indeed increase, thereby raising the cost of borrowing for the affected SOEs (Potelwa 2016). In reflecting on these unintended consequences, Canter reiterated that Futuregrowth's intention was never to punish the country (Canter 2016). He explained: 'We wanted to send a message that we cannot provide finance unless the governance and 
decision-making of the SOE[s] improves and becomes transparent' (Cohen 2016a). On 09 September 2016, Canter personally apologised to the targeted SOEs, Old Mutual and others who felt aggrieved by his public stance (Cohen 2016c; Hogg 2016b; Mokhema \& Gumede 2016).

As indicated earlier, Futuregrowth was under the impression that other asset managers would follow their public activism approach, the argument being that all asset managers faced the same predicament (Hogg 2016b). In Canter's words: 'We all lack information and we all need information to make intelligent investment decisions that we can stand behind and be accountable for' (Canter 2016). Although a few asset managers supported Futuregrowth's decision in principle, nobody followed their public activism approach by coming to the fore (Slabbert 2016). Jyske Bank, a small Danish financier, was the only other investment manager who suspended funding to Eskom (Potelwa \& Cohen 2016).

The reason for the apparent lack of support among local asset managers might be ascribed to the investment community being hesitant to voice their opinion in fear of losing government patronage (Rose et al. 2016). This topic, however, falls beyond the scope of this study.

The Association of Savings and Investments South Africa (ASISA) acknowledged Futuregrowth's fiduciary responsibility towards their clients. Association of Savings and Investments SA's CEO was, however, dismayed about the fact that the association's name was explicitly mentioned in Futuregrowth's announcement. The CEO said: 'We intend to engage pro-actively with our industry colleagues through ASISA so that key concerns can be communicated to the SOEs in a joint manner by the investment industry' (Peyper 2016b). Association of Savings and Investments SA represents the majority of asset managers, collective investment scheme management companies, linked investment service providers, multi-managers and life insurance companies in the country. According to the CEO, the fact that ASISA's name was mentioned created the impression that the lending ban was a decision that ASISA orchestrated. 'And we can't do that. It's illegal'.

In contrast, a prominent banker reacted favourably to the announcement stating that 'this story just ups the ante in what is becoming a high stakes game' (Potelwa 2016). The banker referred to South Africa's reputation in the international arena. A London-based asset consultant likewise remarked:

When the country's largest debt manager pulls the plug on lending to key state-run firms because of concerns about political meddling, it's clear that the country faces a serious reputational problem. (Cohen 2016a)

\section{Findings}

In this section, attention is firstly given to the prevalence of calculative and affective trust in the case study. This is followed by an evaluation of Canter's efforts to resort trust and a discussion on Futuregrowth's views on the unfolding events. Lastly, other asset managers' opinions on Futuregrowth's announcement are highlighted. The structure represents the findings of the content analysis, the interview with Canter and his colleague and the interviews with the six asset managers, respectively.

\section{The prevalence of calculative and affective trust in the case study}

As indicated in Table 2, more words and phrases related to elements of affective trust than those related to calculative trust were revealed during the content analysis.

Words and phrases highlighting Futuregrowth's credibility included 'reasoned and defensible decisions', 'appropriate credit analysis', 'considered assessments', 'deep due diligence', 'detailed review' and 'in-depth understanding'. Journalists stressed the fact that Futuregrowth had a mandate to make 'independent investment calls on behalf of its clients' and that they had 'the right to question' governance at SOEs and other investee companies. Futuregrowth's credibility was underscored by one investor who claimed that he would place his money with fund managers who emulated Futuregrowth as they were 'rational and fiduciary investors'.

Two further comments emphasised Canter's credibility as CIO:

Such is the credibility of Canter that his firm's decision to stop lending money to six South African SOEs knocked the value of the Rand and raised the national cost of borrowing.

and: 'It says much about Futuregrowth CIO Andrew Canter's credibility that his team's decision to stop lending to six SOEs rocked South African markets' (Hogg 2016b). The findings suggest that Canter's announcement was regarded by many as believable and trustworthy. In line with the extant literature, references to credibility were often mentioned in the same breath as those relating to reliability.

Several words and phrases highlighted Futuregrowth's reliability as an asset manager. Recall from Table 1 that reliability refers to the ability to perform a promised service accurately and dependably. As an asset manager, Futuregrowth's fundamental service is to protect clients' money. Most of these references centred on the fact that

TABLE 2: Results of content analysis.

\begin{tabular}{llc}
\hline Dimension & Elements & Number of relevant words and phrases \\
\hline Calculative & Credibility & 20 \\
& Reliability & 15 \\
& Competence & 12 \\
& Uncertainty avoidance & 32 \\
& Total & 79 \\
Affective & Integrity & 28 \\
& Honesty & 7 \\
& Fairness & 15 \\
& Positive feelings & 15 \\
& Negative feelings & 23 \\
& Total & 88 \\
\hline
\end{tabular}


Futuregrowth 'must answer to their clients for decisions made on their behalf' and that they should 'act as checks on borrowers'. Canter made it clear that if Futuregrowth and other asset managers were effective 'caretakers of, and gatekeepers to, people's savings', they could improve the governance and the independence of the targeted SOEs. He illustrated Futuregrowth's sense of responsibility by saying that they 'will no longer risk investors' funds [by lending to the targeted SOEs]' (Hogg 2016a). Other mentions pointing to Futuregrowth's reliability included 'fiduciary investors', 'responsible investors', 'appropriate protections', 'protect our client portfolios from increasing risk', 'we have a duty' and 'we need information and make intelligent investment decisions that we can stand behind and be accountable for it'.

As indicated in Table 1, the element of competence refers to the ability of an institution or individual to meet expectations and to have certain skills. Several words and phrases were identified in the data that illustrate Futuregrowth and Canter's competence. Not only were they described as a 'specialist investment company', but mention was also made of the fact that the investment team had a 'satisfactory balance of skills, experience and independence'. Canter emphasised the fact that this team 'asked relevant questions' and that a 'unanimous decision [was made] by a very racially diverse group of investment professionals applying their minds'. References such as 'conducting a detailed review' and 'doing deep due diligence' illustrate investment rigour, and therefore, competence on the part of Futuregrowth. Perusal of Futuregrowth employees' qualifications (Our people 2018) show that a high premium is placed on professional qualifications and skills.

The trust element that featured the most in this study was that of uncertainty avoidance. This finding was to be expected given political developments at the time of Futuregrowth's announcement. References describing the state of affairs included 'extraordinary times', 'something serious is happening', 'shifting circumstances' and 'difficult period'. It is against this backdrop that Canter said: 'Our message is clear: We cannot provide finance without having clearer sight of, and comfort around, the governance and decision-making of the SOEs' (Le Cordeur 2016). He also mentioned that lending decisions are long-term calls which are 'dependent on the merits at a time'. Canter added that, as rational and fiduciary investors, the team must adapt their views and investment strategies 'when circumstances change'.

It was mentioned that 'whatever this government does, it creates uncertainty, fear, and higher risk for lenders'. It could be argued that Futuregrowth's public announcement added to the uncertainty, especially as calls for more information from investee companies 'are usually made quietly and quickly'. This claim was made on the basis of words and phrases such as 'unprecedented', 'storm', '[Canter] dropped a bit of a bomb', 'shock announcement' and 'breaking ranks to take a stand against the erosion of corporate governance in
SOEs'. In a 2008 study, Beckmann, Menkhoff and Suto (2008) showed that asset managers in countries that score high on Hofstede's uncertainty avoidance dimension typically opt for higher safety margins against the allowed tracking error and generally conduct more research than their counterparts who are more willing to tolerate uncertainty. Although South Africa only has a moderate score for this dimension (Sims \& Gegez 2004), asset managers are bound by fiduciary duties which contribute to them feeling more threatened by unknown situations.

From the preceding extracts, it is clear that Futuregrowth relied heavily on calculative elements of trust to justify their decision to freeze their funding to the SOEs. Reactions to their announcement were, however, more affective in nature. Several references to integrity, which refers to the ability of being morally upright, were identified. Futuregrowth demonstrated integrity by stating that they 'contemplated the public announcement' and that the decision 'was not taken lightly'. On another occasion, Canter remarked that their decision was 'taken with dissonance'.

The asset manager's integrity is evident from the following exclamation by an investor: 'Wow. My respect for the lending industry grew a little. From a low base, I might add. Still. Kudos to them [Futuregrowth]' (Cameron 2016). Futuregrowth's integrity is furthermore apparent from statements made by other asset managers supporting their decision to suspend lending to the targeted SOEs. A number of references also illustrated Canter's integrity as CIO. These included 'noble', 'courageous' and 'daring to challenge'. Commentators also noted that he was 'a good man doing the right thing' and that 'Andrew is a class act-maybe it's time to transfer our pension funds to Futuregrowth!' (Cameron 2016). This evidence of integrity, as displayed by Futuregrowth, is an important component of a financial services relationship, because integrity is a key principle in most codes of ethics governing the financial services professions (Duska 2005).

A further element of affective trust analysed in this study was honesty. References to honesty featured prominently in Canter's public apology. He repeatedly said that the market's reaction 'saddened' him and that it was never his intention to 'undermine the SOEs' developmental missions or disrupt their ability to deliver. He also found it 'grievous' that Old Mutual was 'dragged into a debate which they neither knew about, endorsed, nor could practically control' (Hogg 2016b). These occurrences of honesty, as displayed by Canter's actions, directly feed into trust, because Dowell, Heffernan and Morrison (2013) argue that honesty in words, and actions as well as frank and candid responses are direct drivers of trust. This notion is supported by Ou, Shih and Chen (2015) who not only argue that honesty is one of the key components of trust, but it is also important that employees should always keep honesty constantly at heart.

As fairness is closely intertwined with honesty, many of the same words and phrases relating to honesty were also 
applicable to fairness. Canter went to great lengths to show that his team was impartial in conducting their credit assessments. His comments were particularly aimed at critics who claimed that their decision was 'unfair' and 'racist'. In his apology, Canter, however, conceded that a more measured activism approach would have been a 'fairer process'. From a literature perspective, Canter's efforts to be impartial in terms of conducting credit assessments are in line with the view of Jambulingam, Kathuria and Nevin (2011) that trust can be cultivated through using mechanisms such as fairness, and more specifically procedural fairness (which can be directly linked to Canter's actions).

The largest number of affective words and phrases identified in the case study related to negative feelings. Some of these included 'concerned', 'worried', 'unsettling', 'sombre' and 'horrified'. Most of these words were mentioned in relation to the changing political landscape in South Africa and the higher levels of risk that these changes implied for investors. Rose et al. (2016) even claimed that Canter's announcement was an 'alarm bell', which suggested that the local investment community 'have long suspected but have been too afraid to voice for fear of losing government patronage'. It should be kept in mind that financial markets generally do not favour uncertainty, and that the slightest evidence of instability could unsettle market players. It is therefore not unexpected that the negative sentiments that were created by Futuregrowth's announcement had such an adverse effect on financial markets.

In contrast, markets thrive on positive news, and the fact that some words and phrases of encouragement and hope (reflecting positive) were also expressed, can be viewed as conducive for the formation of trust. Several individuals noticed Canter's 'courage' and 'bravery'. They mentioned that they 'liked' him, were 'impressed' by him, 'respected' him and 'applauded' his decision. Canter himself said that he was 'pleased' that most of the targeted SOEs engaged with them and stressed that Futuregrowth wanted to continue playing a 'positive role in society'.

Most of these dimensions highlighted in the content are deemed critically important by the Chartered Financial Analyst (CFA) Institute and feature prominently in their Code of Ethics and Standards of Professional Conduct. All CFA charterholders and candidates for the CFA designation are required to:

\begin{abstract}
... act with integrity, competence, diligence and respect and in an ethical manner with the public, clients, prospective clients, employers, employees, colleagues in the investment profession and other participants in the global capital markets. (CFA Institute Code of Ethics and Standards of Professional Conduct 2018:1)
\end{abstract}

\section{Evaluating Canter's efforts to restore trust}

Restoring trust is not only a challenging task, but it also occurs over an extended period of time. Therefore, it is of utmost importance that businesses start the process to restore trust as quickly as possible. To rebuild trust in the businessto-business financial services industry (where clients' accounts often run into billions of rands) is especially difficult. As discussed earlier in this article, trust is built on satisfaction, effective communication, competence, customisation and shared values. If these are the building blocks of trust, they collectively become the point of departure to restore trust. Before a judgement can be made in terms of whether or not Futuregrowth has sufficiently commenced to restore trust, it is important to ascertain the asset manager's conduct directly after the announcement. To do this, the conduct of three pertinent stakeholders was analysed, namely the targeted SOEs, Old Mutual and the general public.

Firstly, a few days after the ban was announced and negative feedback started to emerge, Canter issued the following apology:

We must frankly concede that a more measured approach of direct (private) consultation with each SOE would have been a fairer process.... We are pleased that most of the SOEs have engaged and shown a willingness to have deeper discussions about their governance, decision-making and connectivity to spheres of government. (Hogg 2016b)

From a recovery perspective, of which the first step is often to act as quickly as possible, Futuregrowth has lived up to the expectation because the apology was issued almost immediately after the negative responses emerged. Of particular interest is the reference to 'a more measured approach' (Hogg 2016b), which clearly illustrates Futuregrowth's competence, as the company implied its ability to provide this measured approach.

\section{Secondly, Canter (2016a) apologised by saying:}

It is grievous that Old Mutual has been dragged into a debate which they neither knew about, endorsed, nor could practically control. In my view, Old Mutual has shown themselves to be a pro-active and developmentally focused organisation, who has sought to bring about positive change in South Africa.

This apology, which was directed towards Futuregrowth's parent company, is a clear acknowledgement of the possible negative effect that the Futuregrowth ban had on the company's relationship with its parent company. From a relationship perspective, it is evident that Futuregrowth was and remains interested in restoring this important relationship. Not only is a close relationship expected between Futuregrowth and Old Mutual, but it is also assumed that these two companies have to share a congruent set of values. By apologising, the CIO attempted to restore the perception of shared values, which, in turn, fosters trust.

Canter's apology towards the general public was encapsulated in the following statement:

For others who feel aggrieved by our public stance, please accept that our intentions were sound and fiduciary, and the decision was ours alone. We remain committed to partnership with the SOEs in funding South Africa's development. (Hogg 2016b) 
He reiterated that it was never Futuregrowth's intention to undermine the SOEs' developmental mission or ability to deliver public goods. As he did several times before, Canter made it clear that it was never their intention to get involved in politics, although some people interpreted it that way: 'We had no idea of the unanticipated and unintended consequences' (Hogg 2016b). In this apology, Canter adopted a more emotional approach, focusing on the affective side of trust. This third apology, especially if read with and compared to the elements that are listed in Table 1, provides evidence of integrity and honesty.

Futuregrowth's continuous communication and willingness to engage in private conversations with relevant stakeholders are important building blocks of the restoration of trust. Simply, keeping stakeholders well-informed and providing timely and accurate information are essential in rebuilding trust.

\section{Canter's views on the unfolding events}

Canter stated that his team had witnessed SOE governance deteriorating over a long period. It was, however, President Zuma's announcement about the introduction of a new SOE oversight panel that raised the risk associated with these investments significantly. Canter admitted that the decision to go public was taken in haste and conceded that the SOEs in question were subsequently caught off guard. This partially explained their feisty rebuttal. Canter underestimated Futuregrowth's 'voice' and the impact that it would have at the time. The asset manager realised that their 'voice' was indicative of their size, impressive track record over the past 20 years and the fact that they were 'comfortable with who they are', that is, responsible lenders: 'Knowing now that we have a megaphone, we will use it more responsibly'. While Canter apologised for not engaging with the SOEs before the announcement, he remained of the view that private, bilateral discussions would have had minimal results (if any) and over long periods of time.

While Canter agreed that it was inappropriate to bring ASISA's name into the public statement, he repeatedly apologised to them for doing so. He argued that it was only performed as all investors need better governance information and improved reporting, and that it would be more efficient for the SOEs to engage with investors as a group.

Only two of the targeted SOEs (Land Bank and DBSA) gave their full cooperation after Futuregrowth's public call for more information. Two of the other SOEs only agreed to meet selective requests, whereas the remaining two only had intermittent interactions with Canter and his team. Canter contended that, because of interventions at Land Bank, this SOE was in a better position to access funding compared to a year ago.

The events of 31 August 2016, and the subsequent loss of some clients, have resulted in Futuregrowth developing a 'politically contentious issue protocol' with Old Mutual to reduce the holding company's risk as it pertains to Futuregrowth's investor activism. They have also implemented some of the lessons learnt in 2016 in terms of recent engagements, namely starting the direct engagement process earlier and seeking legal advice. All these changes were implemented to enhance Futuregrowth's reputation as a lender that abides by the 'true north' principle. This principle implies that they would not deviate from their fiduciary duties as do so might jeopardise investors' interests.

Canter stressed the fact that they never traded any SOE debt in the weeks before the announcement, they embargoed trading of all six SOEs' bonds after the announcement and retained the embargo until such time as they made public announcements about their findings for each SOE.

\section{Other asset managers' views on Futuregrowth's announcement}

Interviewees claimed that although many of them agreed with Futuregrowth's public stance, the media portrayed a different story. Many asset managers apparently engaged in private with the targeted SOE in the days following Futuregrowth's announcement. Canter also confirmed this assertion during his interview. A few interviewees deemed the risk of speaking out in public as quite significant given that some of the SOEs were existing clients of theirs. One participant indicated that they shared Futuregrowth's sentiments, but claimed that Canter was 'very vocal about it' which was not 'the South African way of doing things'.

\section{Conclusions and recommendations}

Most investor activism in South Africa takes place behind closed doors. Futuregrowth's decision to publicly request more information from six SOEs was therefore quite unconventional. It is clear that the asset manager wanted to make an unequivocal statement about fiduciary duty and sound corporate governance. Through calculative expressions of trust, Canter emphasised Futuregrowth's responsibility to protect ordinary people's life savings by assessing credit risk and acting accordingly. The latter includes withdrawing from investments where the risk of default is becoming too high.

The findings from the content analysis revealed that many of the reactions to Futuregrowth's public activism approach were negative and emotional in nature, suggesting that trust was compromised. The authors are of the opinion that Futuregrowth's ban on future lending was based on sound financial and corporate governance principles, and that Canter was naively unaware of the impact that his 31 August 2016 public statement would have. Canter's sincerity is further apparent in his personal actions to restore trust, namely by apologising in public and by meeting aggrieved stakeholders in private. As the events unfolded, it became clear that this demonstration of public investor activism is a 
classic example of sound intentions that were not interpreted in the same way that they were meant.

Canter acknowledged that trust between Futuregrowth and some of their stakeholders was negatively affected. He also realised that the process to restore trust is dynamic and ongoing. Canter, however, confirmed that the only way of rebuilding trust for Futuregrowth is to continue doing business according to the company's 'true north' philosophy and by exhibiting the essence of calculative trust (credibility, reliability, competence and avoiding uncertainty) and affective trust (particularly integrity, honesty and fairness) in all they do. It could be argued that Canter's apparent naivety, had the biggest negative impact on affective trust. As a result, the importance of managing affective trust could not be neglected in this sector.

This case study illustrates the importance of trust and longterm relationships in the asset management sector. Although some negative consequences resulted from Canter taking a public activism approach, not all stakeholders experienced the situation in this way. For example, Land Bank's full cooperation and consequent improvement in their financial control measures is evidence of how stakeholders can work together to create a win-win situation for all parties involved. Canter knew that rebuilding trust would be a challenging task, but he made no secret of the fact that Futuregrowth always preferred a positive approach; therefore, the lender would remain committed to continued and constructive engagement.

As trust can be easily jeopardised, it is recommended that asset managers who wish to engage with investee companies in South Africa, particularly SOEs, rather do so in private. Speaking out in public should be performed thoughtfully. It is further suggested that asset managers focus on elements of both calculative and affective trust when engaging with investee companies, the media and the public. Given the growing importance of affective trust, as illustrated in this case study and highlighted by Tyler and Stanley (2007), asset managers should not only emphasise credibility, reliability and competence, but they should also give due consideration to integrity and fairness.

In the months since Futuregrowth's public announcement on 31 August 2016, other local asset managers have started to speak out in public. Future researchers could investigate these asset managers' motives for embracing public voice mechanisms. Specific attention could be given to the effectiveness of this voice mechanism.

\section{Acknowledgements Competing interests}

The authors declare that they have no financial or personal relationships that may have inappropriately influenced them in writing this article.

\section{Authors' contribution}

Both authors equally contributed to the writing of this article.

\section{References}

Abdul-Muhmin, A.G., 2005, 'Instrumental and interpersonal determinants of relationship satisfaction and commitment in industrial markets', Journal of Business Research 58(5), 619-628. https://doi.org/10.1016/j.jbusres.2003.08.004

About us, 2018, Futuregrowth Asset Management, viewed 12 January 2018, from http://www.futuregrowth.co.za/about-us/

Alalwan, A.A., Dwivedi, Y.K., Rana, N.P., Lal, B. \& Williams, M.D., 2015, 'Consumer adoption of Internet banking in Jordan: Examining the role of hedonic motivation, habit, self-efficacy and trust', Journal of Financial Services Marketing 20(2), 145157. https://doi.org/10.1057/fsm.2015.5

Anderson, E. \& Weitz, B., 1989, 'Determinants of continuity in conventional industrial channel dyads', Marketing Science 8(4), 310-323. https://doi.org/10.1287/ mksc.8.4.310

Anon, 2016a, FULL STATEMENT: Why Futuregrowth won't grant loans to SOEs, viewed 11 January 2018, from http://www.fin24.com/Economy/full-statement-whyfuturegrowth-wont-grant-loans-to-soes-20160831

Anon, 2016b, Old Mutual distances itself from Futuregrowth's call on state-owned enterprises, viewed 08 January 2018, from http://www.businesslive.co.za/bd/ companies/financial-services/2016-09-01-old-mutual-distances-itself-fromfuturegrowths-call-on-state-owned-enterprises/

Anon, 2016c, Futuregrowth loses R100 million from Eskom pension fund, viewed 07 January 2018, from http://citysun.co.za/futuregrowth-loses-r100-million-eskompension-fund/

Anon, 2016d, 'Minister surprised by money managers' move to withdraw SOE funding', 2016, Eye Witness News, viewed 06 January 2018, from http://ewn. co.za/2016/09/02/Lynn-Brown-didnt-expect-money-managers-to-withdrawfunding-for-SOEs

Aulakh, P.S., Kotabe, M. \& Sahay, A., 1996, 'Trust and performance in crossborder marketing partnerships: A behavioral approach', International Business Studies 27(5), 1005-1032. https://doi.org/10.1057/palgrave.jibs.8490161

Bachmann, R., Gillespie, N. \& Priem, R., 2015, 'Repairing trust in organizations and institutions: Toward a conceptual framework', Organization Studies 36(9), 11231142. https://doi.org/10.1177/0170840615599334

Barry, D., 2009, 'Broken trust shakes web from farmer to cow', New York Times, 23 March, p. A9, A13

Beckmann, D., Menkhoff, L. \& Suto, M., 2008, 'Does culture influence asset managers' views and behavior?', Journal of Economic Behavior \& Organization 67(3-4), 624643. https://doi.org/10.1016/j.jebo.2007.12.001

Bendile, D., 2016, Minister surprised by money managers' move to withdraw SOE funding, viewed 08 January 2018, from http://ewn.co.za/2016/09/02/LynnBrown-didnt-expect-money-managers-to-withdraw-funding-for-SOEs

Berry, L., 1995, 'Relationship marketing of services - Growing interest, emerging perspectives', Journal of the Academy of Marketing Science 23(4), 236-245. https://doi.org/10.1177/009207039502300402

Boshoff, S. \& Schulshenk, J., 2014, 'Responsible investment - Are South Africa's investors committed?', Trialogue, viewed 06 January 2018, from http://www. trialogue.co.za/wp-content/uploads/2014/06/FA Responsibleinvestmentfinal Ir.pdf

Brav, A., Jiang, W., Partnoy, F. \& Thomas, R., 2008, 'Hedge fund activism, corporate governance, and firm performance', The Journal of Finance 63(4), 1729-1775. https://doi.org/10.1111/j.1540-6261.2008.01373.x

Cameron, J., 2016, Investment boycott \& tax strikes: Support grows for financial protests, viewed 06 January 2018, from http://www.fin24.com/BizNews/ investment-boycott-tax-strikes-support-grows-for-financial-protests-20160902

Canary, D.J. \& Cupach, W.R., 1988, 'Relational and episodic characteristics associated with conflict tactics', Journal of Social and Personal Relationships 5(3), 305-325. https://doi.org/10.1177/0265407588053003

Canter, A., 2016, Why others poised to follow Futuregrowth lead, stop lending to SOEs, viewed 06 January 2018, from http://www.fin24.com/BizNews/canter-whyothers-poised-to-follow-futuregrowth-lead-stop-lending-to-soes-20160901

CFA Institute Code of Ethics and Standards of Professional Conduct, 2018, CFA Institute, viewed 03 August 2018, from https://www.cfainstitute.org/en/ethics/ codes/about-code-of-ethics-and-standards, file:///C:/Users/sviviers/Downloads/ code-of-ethics-standards-professional-conduct.pdf

Chong, K. \& Tuckett, D., 2014, 'Constructing conviction through action and narrative: How money managers manage uncertainty and the consequence for financia market functioning', Socio-Economic Review 13(2), 309-330. https://doi. org/10.1093/ ser/mwu020

Chua, R.Y.J., Ingram, P. \& Morris, M.W., 2008, 'From the head and the heart: Locating cognition-and affect-based trust in managers' professional networks' Academy of Management Journal 51(3), 436-452. https://doi.org/10.5465/ amj.2008.32625956

Cohen, M., 2016a, S. Africa's biggest debt manager halts loans to state firms, viewed 08 January 2018, from http://www.bloomberg.com/news/articles/2016-08-31/ south-africa-s-biggest-debt-manager-halts-loans-to-state-firms-isiw5p8u

Cohen, M., 2016b, No panic at Eskom as debt manager halts loans, viewed 05 January 2018, from http://www.fin24.com/Economy/no-panic-at-eskom-as-debtmanager-halts-loans-20160831 
Cohen, M., 2016c, Futuregrowth stands by loan freeze to SA state firms, viewed 07 January 2018, from http://www.fin24.com/Companies/Financial-Services/ 07 January 2018, from http://www.fin24.com/Comp

Coulter, K.S. \& Coulter, R.A., 2003, 'The effects of industry knowledge on the development of trust in service relationships', International Journal of Research in Marketing 20(1), 31-43. https://doi.org/10.1016/S0167-8116(02)00120-9

Damasio, A.R., 2004, 'Emotions and feelings', in S.R. Manstead (ed.), Feelings and emotions: The Amsterdam symposium, pp. 49-57, Cambridge University Press, Cambridge, UK. https://doi.org/10.1017/CBO9780511806582.004

Devlin, J.F., Ennew, C.T., Sekhon, H.S. \& Roy, S.K., 2015, 'Trust in financial services: Retrospect and prospect', Journal of Financial Services Marketing 20(4), 234-245. https://doi.org/10.1057/fsm.2015.21

Dowell, D., Heffernan, T. \& Morrison, M., 2013, 'Trust formation at the growth stage of a business-to-business relationship: A qualitative investigation', Qualitative Market Research: An International Journal 16(4), 436-451. https://doi. org/10.1108/QMR-06-2011-0006

Dowell, D., Morrison, M. \& Heffernan, T., 2015, 'The changing importance of affective trust and cognitive trust across the relationship lifecycle: A study of business-tobusiness relationships', Industrial Marketing Management 44, 119-130. https:// doi.org/10.1016/j.indmarman.2014.10.016

Duska, R.F., 2005, 'A look at integrity in financial services', Journal of Financial Service Professionals 59(5), 26-28.

Edelman Trust Barometer, 2017a, Global annual study, 2017, Global results, viewed 09 January 2018, from http://www.edelman.com/trust2017/

Edelman Trust Barometer, 2017b, 2017 trust in financial services, viewed 05 January 2018, from https://www.edelman.com/post/accelerating-trust-in-financialservices/

Elo, S. \& Kyngäs, H., 2007, 'The qualitative content analysis process', Journal of Advanced Nursing 62(1), 107-115. https://doi.org/10.1111/j.1365 2648.2007.04569.x

Ennew, C. \& Sekhon, H., 2007, 'Measuring trust in financial services: The trust index', Consumer Policy Review 17(2), 62-68.

Finfgeld-Connett, D., 2014, 'Use of content analysis to conduct knowledge-building and theory-generating qualitative systematic reviews', Qualitative Research 14(3), 341-352. http://journals.sagepub.com/doi/pdf/10.1177/1468794113481790

Garbarino, E. \& Johnson, M.S., 1999, 'The different roles of satisfaction, trust and commitment in customer relationships', Journal of Marketing 63(2), 70-87. https://doi.org/10.2307/1251946

Gill, A.S., Flaschner, A.B. \& Shachar, M., 2006, 'Factors that affect the trust of business clients in their banks', International Journal of Bank Marketing 24(6), 384-405. https://doi.org/10.1108/02652320610701726

Gounaris, K.M. \& Prout, M.F., 2009, 'Repairing relationships and restoring trust: Behavioral finance and the economic crisis', Journal of Financial Service Professionals 63(4), 75-84.

Green, C.H., 2014, 'Trust me!', ABA Bank Marketing \& Sales 46(1), 14-20.

Hansen, T., 2014, 'The role of trust in financial customer - Seller relationships before and after the financial crisis', Journal of Consumer Behaviour 13(6), 442-452. https://doi.org/10.1002/cb.1493

Hogg, A., 2016a, Futuregrowth's Andrew Canter sparks a financial revolution - Or not, viewed 11 January 2018, from http://www.fin24.com/BizNews/futuregrowthsandrew-canter-sparks-a-financial-revolution-or-not-20160901

Hogg, A., 2016b, Futuregrowth ClO recants: 'Had no idea of the unintended consequences, viewed 09 January 2018, from http://www.fin24.com/ BizNews/futuregrowth-cio-recants-had-no-idea-of-the-unintendedconsequences-20160909

Homburg, C., Giering, A. \& Menon, A., 2003, 'Relationship characteristics as moderators of the satisfaction-loyalty link: Findings in a business-to-business context', Journal of Business-to-Business Marketing 10(3), 35-62. https://doi. org/10.1300/J033v10n03_02

Hsieh, H-F. \& Shannon, S.E., 2005, 'Three approaches to qualitative conten analysis', Qualitative Health Research 15(9), 1277-1288, https://doi. org/10.1177/1049732305276687

Hurley, R., Gong, X. \& Waqar, A., 2014, 'Understanding the loss of trust in large banks', International Journal of Bank Marketing 32(5), 348-366. https://doi.org/10.1108/ IJBM-01-2014-0003

Jambulingam, T., Kathuria, R. \& Nevin, J.R., 2011, 'Fairness-trust-loyalty relationship under varying conditions of supplier-buyer interdependence', Journal of Marketing Theory and Practice 19(1), 39-56. https://doi.org/10.2753/MTP1069Marketing Theor
6679190103

Johnson, D. \& Grayson, K., 2005, 'Cognitive and affective trust in service relationships', Journal of Business Research 58(4), 500-507, https://doi.org/10.1016/S01482963(03)00140-1

Kang, I., Jeon, S., Lee, S. \& Lee, C.-K., 2005, 'Investigating structural relations affecting the effectiveness of service management', Tourism Management 26(3), 301-310. https://doi.org/10.1016/j.tourman.2004.02.006

Kolstad, I., 2016, 'Three questions about engagement and exclusion in responsible investment', Business Ethics: A European Review 25(1), 45-58. https://doi. org/10.1111/beer.12107

Le Cordeur, M., 2016, Futuregrowth lifts funding ban against 2nd SOE, viewed 06 January 2018, from http://www.fin24.com/Companies/Financial-Services/ futuregrowth-lifts-funding-ban-against-2nd-soe-20161107

Leisen, B. \& Hyman, M.R., 2004, 'Antecedents and consequences of trust in a service provider. The case of primary care physicians', Journal of Business Research 57(9), 990-999. https://doi.org/10.1016/S0148-2963(02)00343-0
Maake, M., 2016, Futuregrowth lifts ban on DBSA, viewed 11 January 2018, from https://www.businesslive.co.za/bd/companies/2016-11-21-futuregrowth-liftsban-on-dbsa/

MacMillan, K., Money, K., Money, A. \& Downing, S., 2005, 'Relationship marketing in the not-for-profit sector: An extension and application of the commitment-trust theory', Journal of Business Research 58(6), 806-818. https://doi.org/10.1016/j. jbusres.2003.08.008

Market Profile June 2018, 2018, JSE, viewed 06 January 2018, from https://www. jse.co.za/content/JSEEquityMarketProfileltems/JSE\%20Markets $\% 20$ Profile $\% 20$ 20180630.pdf

McNulty, T. \& Nordberg, D., 2016, 'Ownership, activism and engagement: Institutional investors as active owners', Corporate Governance: An International Review 24(3), 346-358. https://doi.org/10.1111/corg.12143

Metzger, M.J. \& Flanagin, A.J., 2013, 'Credibility and trust of information in online environments: The use of cognitive heuristics', Journal of Pragmatics 59, 210-220. https://doi.org/10.1016/j.pragma.2013.07.012

Moin, S.M.A., Devlin, J. \& McKechnie, S., 2015, 'Trust in financial services: Impact of institutional trust and dispositional trust on trusting belief', Journal of Financia Services Marketing 20(2), 91-106. https://doi.org/10.1057/fsm.2015.6

Mokhema, T. \& Gumede, A., 2016, Futuregrowth standoff with state firms thaws, viewed 05 January 2018, from http://www.fin24.com/Companies/FinancialServices/futuregrowth-standoff-with-state-firms-thaws-20160926

Moola, N., 2017, Interest bill has already crept up, but this is still the calm before the storm, viewed 05 January 2018, from https://www.businesslive.co.za/bd/ opinion/2017-05-12-interest-bill-has-already-crept-up-but-this-is-still-the-calmbefore-the-storm/

Moorman, C., Deshpandé, R. \& Zaltman, G., 1993, 'Factors affecting trust in market research relationships', Journal of Marketing 57(1), 81-101. https://doi. org/10.2307/1252059

Morgan, R.M. \& Hunt, S.D., 1994, 'The commitment-trust theory of relationship marketing', Journal of Marketing 58(3), 20-38. https://doi.org/10.2307/1252308

Muylle, S. \& Standaert, W., 2016, 'The use of procedural fairness in electronic reverse auctions to enhance relationship quality', Psychology \& Marketing 33(4), 283296. https://doi.org/10.1002/mar.20875

Omarjee, L., 2016, Treasury backs Brown on SOE issues, viewed 06 January 2018, from http://www.fin24.com/Economy/treasury-backs-brown-on-soe-issues-20160831

Ou, W.M., Shih, C.M. \& Chen, C.Y., 2015, 'Effects of ethical sales behaviour on satisfaction, trust, commitment, retention and words-of-mouth', Internationa Journal of Commerce and Management 25(4), 673-686. https://doi.org/10.1108/ IJCOMA-04-2013-0040

Our people, 2018, Futuregrowth, viewed 06 August 2018, from http://www. futuregrowth.co.za/about-us/our-people/investment-team/

Perry, C., Cavaye, A. \& Coote, L., 2002, 'Technical and social bonds within business-tobusiness relationships', Journal of Business \& Industrial Marketing 17(1), 75-88. https://doi.org/10.1108/08858620210415217

Peyper, L., 2016a, Transnet capex programme could impact on cash flows - Moody's, viewed 06 January 2018, from http://www.fin24.com/Economy/transnet-capexprogramme-could-impact-on-cash-flows-moodys-20160920

Peyper, L., 2016b, Futuregrowth's SOE stance under fire, viewed 06 January 2018, from http://www.fin24.com/Economy/futuregrowths-soe-stance-underfire-20160906

Pi, S.M., Liao, H.L. \& Chen, H.M., 2012, 'Factors that affect consumers' trust and continuous adoption of online financial services', International Journal of Business and Management 7(9), 108-119. https://doi.org/10.5539/ijbm.v7n9p108

Pinto, J.K., Slevin, D.P. \& English, B., 2009, 'Trust in projects: An empirical assessment of owner/contractor relationships', International Journal of Project Management 27(6), 638-648. https://doi.org/10.1016/j.ijproman.2008.09.010

Potelwa, X., 2016, Rand slumps as Futuregrowth suspends loans to state firms, viewed 05 January 2018, from http://www.fin24.com/Markets/Currencies/rand-slumpsas-futuregrowth-halts-loans-to-state-firms-20160831

Potelwa, X. \& Cohen, M., 2016, Jyske joins Futuregrowth, 'Pulls Plug' on S. Africa's Eskom, viewed 08 January 2018, from http://www.bloomberg.com/news/ articles/2016-09-01/jyske-joins-futuregrowth-pulls-plug-on-south-africa-seskom

Rempel, J.K., Holmes, J.G. \& Zanna, M.P., 1985, 'Trust in close relationships', Journal of Personality and Social Psychology 49(1), 95-112. https://doi.org/10.1037/0022 3514.49.1.95

Román, S., 2003, 'The impact of ethical sales behaviour on customer satisfaction, trust and loyalty to the company: An empirical study in the financial services industry' Journal of Marketing Management 19(9-10), 915-939. https://doi.org/10.1080/ 0267257X.2003.9728245

Rose, R., Hasenfuss, M. \& Bisseker, C., 2016, A line in the sand, viewed 07 January 2018, from http://www.financialmail.co.za/coverstory/2016/09/08/a-line-in-thesand

Ryan, L.V. \& Schneider, M., 2002, 'The antecedents of institutional investor activism', Academy of Management Review 27(4), 554-573. https://doi.org/10.5465/ amr.2002.7566068

Selnes, F., 1998, 'Antecedents and consequences of trust and satisfaction in buyerseller relationships', European Journal of Marketing 32(3/4), 305-322. https://doi. org/10.1108/03090569810204580

Sims, R.L. \& Gegez, A.E., 2004, 'Attitudes towards business ethics: A five nation comparative study', Journal of Business Ethics 50(3), 253-265, viewed 01 April 2018 , from https://link.springer.com/article/10.1023/B:BUSI.0000024708.07201.2d 
Slabbert, A., 2016, Futuregrowth investment freeze won't affect us - Eskom, viewed 06 January 2018, from http://www.moneyweb.co.za/news/south-africa/ futuregrowth-investment-freeze-wont-affect-us-eskom

Smith, C., 2016, SOEs already talking to Futuregrowth, viewed 06 January 2018, from http://www.fin24.com/Economy/soes-already-talking-tofuturegrowth-20160901

Smith, J.B. \& Barclay, D.W., 1997, 'The effects of organizational differences and trust on the effectiveness of selling partner relationships', Journal of Marketing 61(1), 3-21. https://doi.org/10.2307/1252186

Thompson, W., 2017, Transnet bond auction fails to entice, viewed 08 January 2018 from https://www.moneyweb.co.za/news/markets/transnet-bond-auction-failsto-entice/

Tran, T.X., Nguyen, T.L. \& Nguyen, T.H., 2016, 'Affect of uncertainty avoidance on venture capital investing activities in Asian countries', Asian Social Science 12(12), 152. https://doi.org/10.5539/ass.v12n12p152

Turner, R.E., Edgley, C. \& Olmstead, G., 1975, 'Information control in conversations: Honesty is not always the best policy', Kansas Journal of Sociology 11(1), 69-89. Honesty is not always the best policy', Kans
https://doi.org/10.17161/STR.1808.6098

Tyler, K. \& Stanley, E., 2007, 'The role of trust in financial services business relationships', Journal of Services Marketing 21(5), 334-344. https://doi. org/10.1108/08876040710773642

Uslaner, E.M., 2010, 'Trust and the economic crisis of 2008', Corporate Reputation Review 13(2), 110-123. https://doi.org/10.1057/crr.2010.8

Vašková, N. \& Vašková, V., 2010, 'Breakdown of trust in financial institutions', Journal of Advanced Studies in Finance 1(1), 108-114.

Viviers, S. \& Smit, E.vdM., 2015, 'Institutional proxy voting in South Africa: Process, outcomes and impact', South African Journal of Business Management 46(3), 23-34. https://doi.org/10.4102/sajbm.v46i4.106

Wang, S.W., Ngamsiriudom, W. \& Hsieh, C.H., 2015, 'Trust disposition, trust antecedents, trust, and behavioral intention', The Service Industries Journal 35(10), 555-572. https://doi.org/10.1080/02642069.2015.1047827
Warrington, T.B., Abgrab, N.J. \& Caldwell, H.M., 2000, 'Building trust to develop competitive advantage in e-business relationships', Competitiveness Review 10(2), 160-169. https://doi.org/10.1108/eb046409

Wen, S., 2009, 'Institutional investor activism on socially responsible investment: Effect and expectations', Business Ethics: A European Review 18(3), 308-333. https://doi.org/10.1111/j.1467-8608.2009.01565.x

Williams, J.J., Deodutt, J. \& Stainbank, L.J., 2016, 'An analysis of director interlocks on the Johannesburg Stock Exchange', South African Journal of Accounting Research 30(2), 120-138. https://doi.org/10.1080/10291954.2015.1099203

Wilson, J.M., Straus, S.G. \& McEvily, B., 2006, 'All in due time: The development of trust in computer-mediated and face-to-face teams', Organizational Behavior and Human Decision Processes 99(1), 6-33. https://doi.org/10.1016/j. obhdp.2005.08.001

Wu, X.N., Wu, X. \& Wang, W., 2016, 'How do cognitive and affective trust impact process outcome interaction?', Social Behavior and Personality: An International Journal 44(8), 1395-1407. https://doi.org/10.2224/sbp.2016.44.8.1395

Xifei, F. \& Jin, Q., 2015, 'The five dimensions of e-tailing service reliability', Journal of Marketing Development and Competitiveness 9(1), 83-92.

Yilmaz, C., Sezen, B. \& Ozdemir, O., 2005, 'Joint and interactive effects of trust and (inter)dependence on relational behaviors in long-term channel dyads', Industrial Marketing Management 34(4), 235-248. https://doi.org/10.1016/j. indmarman.2004.07.005

Young-Ybarra, C. \& Wiersema, M., 1999, 'Strategic flexibility in information technology alliances: The influence of transaction cost economics and social exchange theory', Organization Science 10(4), 439-459. https://doi.org/10.1287/orsc.10.4.439

Zaheer, A., McEvily, B. \& Perrone, V., 1998, 'Does trust matter? Exploring the effect of interorganizational and interpersonal trust on performance', Organization Science 9(2), 141-159. https://doi.org/10.1287/orsc.9.2.141

Zur, A., Leckie, C. \& Webster, C.M., 2012, 'Cognitive and affective trust between Australian exporters and their overseas buyers', Australasian Marketing Journa 20(1), 73-79. https://doi.org/10.1016/j.ausmj.2011.08.001 